\title{
Struktur Kepemilikan Dan Karakteristik Perusahaan Terhadap Agresivitas Pajak Perusahaan Manufaktur Di Indonesia
}

\author{
Nova Choirul Anwar Pratama1, Siti Nurlaela ${ }^{2}$, Kartika Hendra Titisari ${ }^{3}$ \\ 1-2-3Jurusan Akuntansi, Universitas Islam Batik Surakarta \\ Email: nov4cho1rul@gmail.com \\ Email: dra.nurlaela90@gmail.com \\ Email: kartikatitisari@gmail.com
}

\begin{abstract}
The government and taxpayers have different interests, thus raising the tendency of taxpayers to minimize the tax paid. This research purpose to determine and analyze the impact of ownership structure (managerial ownership and institutional ownership) and firm characteristics (liquidity, gender diversity on board) on tax aggressiveness. For this research 134 manufacturing firms listed on Indonesia Stock Exchange in the 2013-2018 period used as population. By using purposive sampling selected 12 firms that used to be sample. Analytical method used is panel data regression and model selected Random Effect in Eviews 9. Research findings that liquidity affects tax aggressiveness, while other variable managerial ownership, institutional ownership, and gender diversity on the board do not have an impact on tax aggressiveness.
\end{abstract}

Keywords: Ownership Structur, Firm Characteristic, Tax Aggressiveness

Abstrak

Pemerintah dan wajib pajak memiliki perbedaan kepentingan, sehingga menimbulkan kecenderungan wajib pajak meminimalkan pajak yang dibayarkan. Penelitian ini bertujuan untuk mengetahui dan menganalisis pengaruh struktur kepemilikan (kepemilikan manajerial, kepemilikan institusional) dan karakteristik perusahaan (likuiditas, gender diversity pada dewan) terhadap agresivitas pajak. Dalam penelitian ini 134 perusahaan manufaktur yang terdaftar di BEI periode 2013-2018 digunakan sebagai populasi. Dengan menggunakan purposive sampling terpilih 12 perusahaan yang memenuhi kriteria sampel. Metode analisis yang digunakan adalah regresi data panel dan model yang dipilih Random Effect dengan program Eviews 9. Hasil penelitian menunjukkan bahwa likuiditas berpengaruh terhadap agresivitas pajak, sedangkan variabel kepemilikan manajerial, kepemilikan institusional, dan gender diversity pada dewan tidak memiliki pengaruh terhadap agresivitas pajak.

Kata kunci: Struktur Kepemilikan, Karakteristik Perusahaan, Agresivitas Pajak

\section{Pendahuluan}

Hingga tahun 2019 pajak masih diharapkan mampu memberikan kontribusi tertinggi kepada penerimaan Indonesia. Pada APBN 2019, dari Rp. 2.165,1 triliun pendapatan negara diharapkan Rp. 1.786,4 triliun atau sekitar 82,5 \% berasal dari sektor pajak (Kementrian Keuangan Republik Indonesia, 2019). Indonesia termasuk kedalam 4 negara di Asia yang mempunyai nilai tambah sektor industri tertinggi di dunia. Sektor manufaktur adalah kontributor terbesar yang mendorong terjadinya pertumbuhan ekonomi Indonesia pada tahun 2018 (Kompas, 2019). Organisasi Kerja Sama dan 
Pembangunan Ekonomi atau disingkat OECD pada laporan terbaru tahun 2019 memposisikan tax ratio Indonesia di peringkat terbawah dengan 11,5 \% jauh jika dibandingkan Selandia Baru (32\%) atau rata-rata negara di Afrika (18,2\%). Penghindaran pajak dan basis pemajakan yang rendah merupakan salah satu faktor rendahnya tax ratio Indonesia, menurut laporan tersebut.

Pendapat perusahaan, laba perusahaan yang diperoleh tidak dapat optimal dan menurun karena beban yang harus ditanggung oleh pajak atas penghasilan perusahaan. Realita tersebut mendorong perusahaan sebisa mungkin membuat keputusan yang bisa memposisikan perusahaan membayar pajak paling sedikit. Karenanya, berbagai cara dipakai perusahaan untuk "mengakali" regulasi yang ada. Diantaranya dengan tindakan penghindaran pajak maupun lebih agresif saat melaporkan pajak (Octaviani \& Sofie, 2018). Menurut Onyali \& Okafor (2018) agresivitas pajak merupakan kegiatan untuk merepresentasikan perbedaan penanganan aktivitas untuk mengurangi pajak penghasilan yang dibayarkan dan dapat melanggar peraturan yang berlaku maupun tidak.

Berbagai temuan penelitian yang berperan mendorong penelitian ini adalah penelitian Wijaya \& Saebani (2019) yang mengemukakan kepemilikan manajerial berpengaruh pada agresivitas pajak. Berlawanan dengan penelitian Salaudeen \& Ejeh (2018) dan Octaviani \& Sofie (2018). Kepemilikan institusional mempengaruhi agresivitas pajak menurut Sadjiarto, Florencia, \& Nevanda (2019), berbanding terbalik dengan hasil penelitian Octaviani \& Sofie (2018). Penelitian tentang likuiditas terhadap agresivitas pajak telah dilakukan oleh Kariimah \& Septiowati (2019) serta Djohar \& Rifkhan (2019). Sedangkan, likuiditas dianggap tidak mampu mempengaruhi agresivitas pajak berdasarkan pada penelitian Nurjanah, Hanum, \& Alwiyah (2018). Di Nigeria, penelitian sebelumnya mengemukakan bahwa gender diversity pada dewan mempengaruhi agresivitas pajak (Onyali \& Okafor, 2018). Berlawanan dengan penelitian Edwin \& Victor (2019) yang mengemukakan keberagaman gender pada dewan tidak dapat berpengaruh pada agresivitas pajak.

Fenomena dan hasil yang tidak konsisten diatas, menyebabkan peneliti bermaksud meneliti kembali tentang agresivitas pajak yang ditinjau dari beberapa variabel yang disinggung diatas yaitu kepemilikan manajerial, kepemilikan institusional, likuiditas dan gender diversity pada dewan pada perusahaan manufaktur tahun 2013-2018 yang ada di BEI. Yang membedakan penelitian ini dibandingkan penelitian yang telah ada sebelumnya adalah, penelitian ini berusaha mengkombinasikan variabel independen dari penelitian sebelumnya yang belum konsisten, sampel perusahaan yang digunakan serta periode penelitian.

\section{Landasan Teori}

Signaling Theory

Menurut Simarmata \& Cahyonowati (2014) signaling theory mengemukakan mengenai seperti apa semestinya suatu perusahaan menyampaikan sinyal untuk pengguna laporan keuangan yang dimaksud disini adalah investor dan kreditur serta pengguna lainnya. Sinyal ini merupakan informasi tentang bagaimana kinerja manajemen untuk mewujudkan tujuan pemilik. Manajemen mengasumsikan praktik meminimalkan pajak yang telah dijalankan mampu menghasilkan laba bersih yang lebih optimal. Lalu diproyeksikan dapat diterima sebagai kode positif oleh pemangku kepentingan sehingga dapat menambah kekayaan perusahaan yang dicerminkan dengan kondisi saham dari masa ke masa yang lebih meningkat harganya (Simarmata \& Cahyonowati, 2014). Pelaporan 
pajak yang lebih agresif terbantu dengan regulasi penggunaan sistem self assessment yang berjalan di Indonesia. Menyerahkan sepenuhnya perusahaan untuk memperhitungkan dan dilaporkan oleh wajib pajak secara mandiri. Kondisi ini memudahkan perusahaan mengontrol laba yang ingin diakui sehingga membantu perusahaan menyampaikan kode kepada para pemegang atau pemilik saham serta segenap calon (Kariimah \& Septiowati, 2019).

\section{Teori Stakeholder}

Makhfudloh, Herawati, \& Wulandari (2018) mengemukakan teori stakeholder dikembangkan dari prespektif yang timbul dari hubungan antara perusahaan dengan seluruh pemangku kepentingan. Fokus perusahaan diharapkan tidak terpaku pada pemegang saham saja melainkan harus memikirkan semua pemangku kepentingan tanpa terkecuali. Perusahaan wajib ikut serta bertanggung jawab terhadap segala pihak yang terdampak dari kegiatan usahanya. Stakeholder pada dasarnya mampu mengontrol atau mempunyai kuasa untuk bisa mengendalikan penyaluran sumber daya ekonomi yang direalisasikan oleh perusahaan.

\section{Teori Legitimasi}

Teori legitimasi menggambarkan jika perusahaan bagaimanapun juga harus melakukan kegiatan usahanya sesuai nilai-nilai keadilan yang berkembang pada masyarakat, karena secara tidak langsung perusahaan mempunyai kontrak dengan masyarakat (Prasista \& Setiawan, 2016). Perusahaan bukan hanya harus memperhatikan hak-hak pemegang saham saja melainkan juga harus memikirkan hak-hak masyarakat yang tidak terlepas dari tanggung jawabnya (Prasista \& Setiawan, 2016).

\section{Agresivitas Pajak}

Agresivitas pajak pada dasarnya adalah konsep yang sangat luas yang termasuk didalamnya melliputi perencanaan pajak atau praktik penghindaran pajak serta praktik penggelapan pajak (Salman, Anshori, \& Tjaraka, 2018). Menurut Onyali \& Okafor, (2018) agresivitas pajak merupakan kegiatan untuk merepresentasikan perbedaan penanganan aktivitas untuk mengurangi pajak penghasilan yang dibayarkan dan dapat melanggar peraturan yang berlaku maupun tidak.

\section{Struktur Kepemilikan}

Struktur kepemilikan menjelaskan proporsi kepemilikan saham yang terdapat pada sebuah perusahaan, serta bagaimana tindakan yang dilakukan pemilik saham tersebut (Petta \& Tarigan, 2017). Struktur kepemilikan yang akhirnya dipilih pada penelitian ini adalah kepemilikan manajerial serta kepemilikan institusional.

Kepemilikan manajerial mencerminkan saham yang menjadi milik manajemen baik itu komisaris maupun direksi, yang digambarkan oleh banyaknya saham manajemen dalam pengambilan keputusan perusahaan. Manakala terjadi kesalahan dalam penentuan keputusan, manajemen secara sadar maupun tidak akan ikut terdampak karena sahamsahamnya ditanamkan dalam perusahaan (Wijaya \& Saebani, 2019). Agar dapat mengendalikan perusahaan dengan leluasa, manajemen harus memiliki saham yang mayoritas ada. Karena jika demikian, kedudukan manajemen menjadi pemilik saham secara bersamaan, dan dapat secara selaras berusaha memperoleh kesejahteraan bagi pemilik (Wijaya \& Saebani, 2019). 
Kepemilikan institusional yaitu kepemilikan suatu perusahaan yang sahamnya milik berbagai bentuk lembaga ataupun perusahaan lainya, baik itu didalam maupun luar negeri (Singal \& Putra, 2019). Kepemilikan institusional difungsikan sebagai penjamin manajemen perusahaan memberikan kebijakan yang dapat mengoptimalkan pemegang saham lebih diuntungkan.

\section{Karakteristik Perusahaan}

Sifat yang sangat mengikat pada setiap perusahaan dan mampu dilihat oleh bermacam sisi merupakan karakteristik perusahaan (Wijayanti et al 2017). Karakteristik perusahaan yang dipakai pada penelitian ini adalah likuiditas dan gender diversity pada dewan.

Likuiditas menunjukkan bagaimana perbandingan antara aset lancar dan utang lancar perusahaan (Nurlaela et al 2019). Menurut Kariimah \& Septiowati (2019) tingkat likuiditas digunakan investor maupun calon investor untuk melihat keadaan suatu perusahaan. Tingginya nilai rasio likuiditas akan memberi dampak semakin memikat perusahaan dimata investor.

Gender diversity pada dewan adalah keragaman jenis kelamin pada direksi dan komisaris dan diukur melalui total wanita dibandingkan dengan jumlah pria pada posisi tersebut (Onyali \& Okafor, 2018). Keberagaman gender pada dewan perusahaan dapat memberikan pandangan lain untuk menyelesaikan masalah dan mengambil keputusan dengan alternatif baru didalam perusahaan (Lanis, Richardson, \& Taylor, 2017).

\section{Kepemilikan Manajerial dan Agresivitas Pajak}

Jika dalam sebuah manajemen perusahaan merupakan pemegang sebagian besar saham maka dapat mendorong mereka sehingga menjaga kinerja perusahaan. Manajerial lebih berorientasi untuk mengoptimalkan keuntungan dan berusaha sedikit mungkin membayar pajak, karena manajerial berperan ganda sebagai pemegang saham dan manajemen (Wijaya \& Saebani, 2019). Sesuai dalam penelitian Wijaya \& Saebani (2019) mengemukakan bahwa kepemilikan manajerial dapat berpengaruh pada agresivitas pajak suatu entitas usaha. Sesuai teori dan penelitian yang sudah dilakukan sebelumnya, hipotesis yang dipakai seperti berikut :

H1 : Kepemilikan manajerial berpengaruh terhadap agresivitas pajak

\section{Kepemilikan Institusional dan Agresivitas Pajak}

Menurut Sadjiarto et al. (2019) kepemilikan institusional yang tinggi dapat mengawasi manajemen lebih intens. Maka dapat memberi tekanan kepada manajemen agar tidak agresif melakukan agresivitas pajak. Kepemilikan institusional mempengaruhi agresivitas pajak oleh (Sadjiarto et al., 2019). Sesuai teori serta penelitian oleh peneliti sebelumnya, hipotesis yang dipakai sebagai berikut :

H2 : Kepemilikan institusional berpengaruh terhadap agresivitas pajak

\section{Likuiditas dan Agresivitas Pajak}

Likuiditas akan berdampak pada cara perusahaan untuk memperlakukan beban pajaknya, karena likuiditas dapat menyebabkan perubahan pada tingkat laba yang akan diperolehnya (Djohar \& Rifkhan, 2019). Penelitian tentang likuiditas berpengaruh pada agresivitas pajak telah dibuat oleh Kariimah \& Septiowati (2019) serta Djohar \& Rifkhan 
(2019). Sesuai teori dan penelitian yang sudah dilakukan sebelumnya, hipotesis yang dipakai sebagai berikut :

H3 : Likuiditas berpengaruh terhadap agresivitas pajak

\section{Gender Diversity pada Dewan dan Agresivitas Pajak}

Menurut Onyali \& Okafor (2018) kehadiran wanita dalam dewan perusahaan akan menyebabkan perusahaan lebih hati-hati dalam membuat keputusan, termasuk dalam pelaporan pajaknya. Penelitian sebelumnya mengemukakan gender diversity pada dewan mampu mempengaruhi tingkat agresivitas (Onyali \& Okafor, 2018). Sesuai teori dan penelitian yang sudah dilakukan sebelumnya, hipotesis yang dipakai sebagai berikut :

H4 : Gender diversity pada dewan berpengaruh terhadap agresivitas pajak

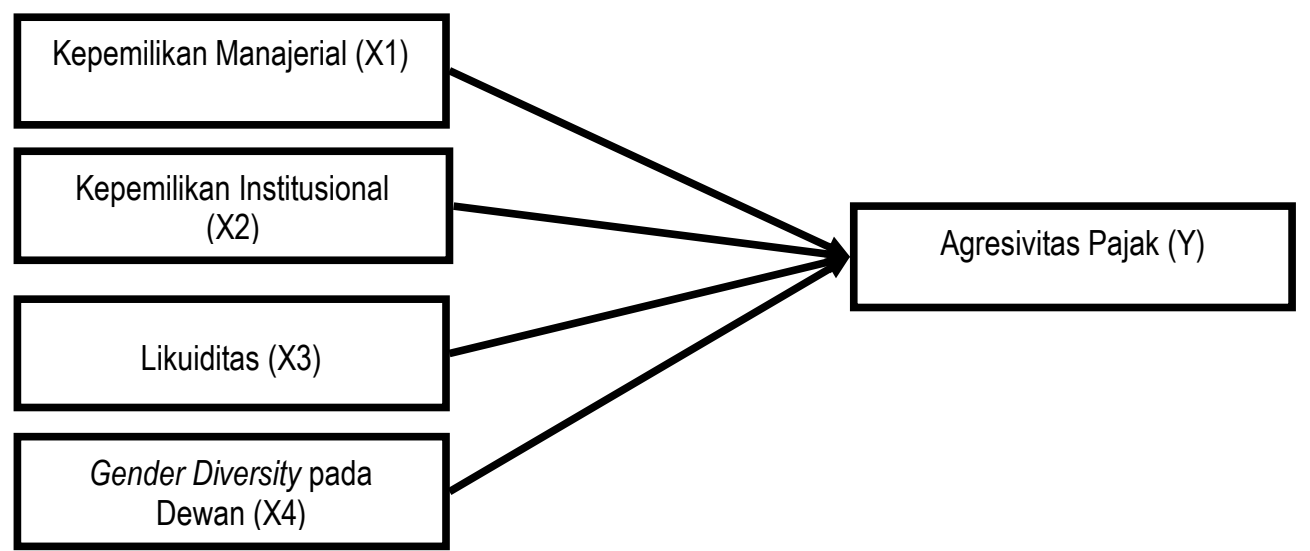

Gambar 1. Kerangka Pemikiran
Sumber: Analisis Penulis

\section{METODE PENELITIAN}

Menurut jenis data yang dipilih untuk dipakai, penelitian ini termasuk dalam kategori penelitian kuantitatif. Data sekunder dalam bentuk dokumentasi laporan keuangan dan laporan tahunan perusahaan yang diterbitkan dan dikutip dari website resmi milik Bursa Efek Indonesia maupun milik perusahaan. Peneliti menggunakan 134 perusahaan manufaktur pada BEI selama periode 2013 - 2018 menjadi populasi. Untuk didapatkan hasil pengaruh antar variabel pada penelitian ini dipilih analisis regresi data panel pada aplikasi Eviews 9. Dari 134 perusahaan manufaktur, dengan beberapa kriteria diperoleh 12 perusahaan yang masuk kriteria dan dipakai untuk sampel sebagai berikut :

Tabel 2. Ketentuan Pemilihan Sampel

\begin{tabular}{|c|c|c|}
\hline No & Keterangan & Jumlah \\
\hline 1. & Perusahaan manufaktur BEl periode 2013-2018 & 134 \\
\hline 2. & Perusahaan menggunakan mata uang selain rupiah. & (29) \\
\hline 3. & Memiliki laba negatif selama tahun pengamatan & (39) \\
\hline \multirow[t]{3}{*}{4.} & Tidak memiliki kelengkapan data yang diperlukan. & (54) \\
\hline & Sampel yang memenuhi kriteria & 12 \\
\hline & Jumlah sampel (12 x 6 tahun) & 72 \\
\hline
\end{tabular}

Sumber : Pengolahan data (2019)

Tabel 1. Definisi Operasional Variabel 


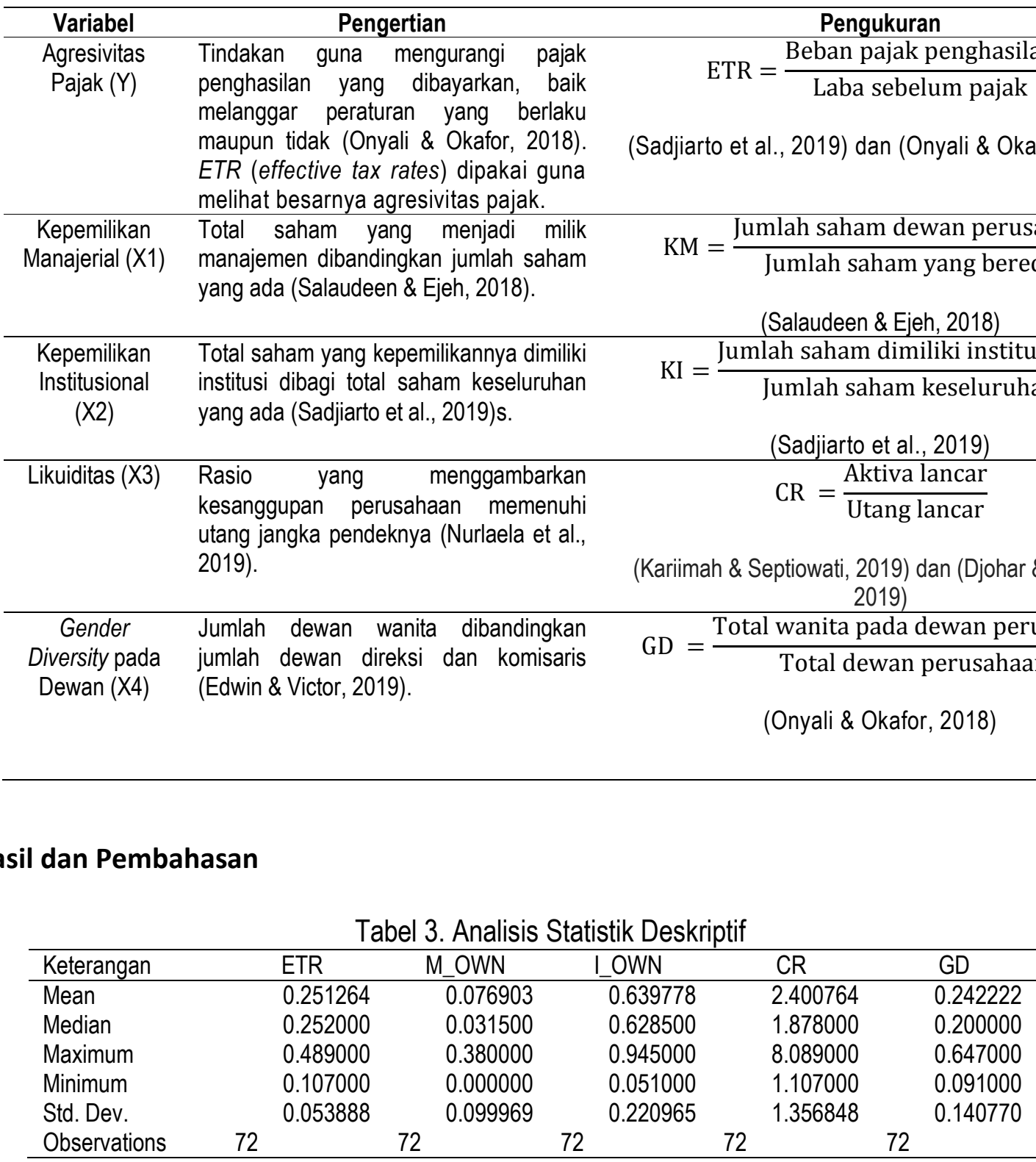

Sumber : Pengolahan data (2019)

Dari Tabel 3. Dapat diketahui informasi umum mengenai variabel dalam penelitian ini. Ratarata ETR selama tahun penelitian berada di 0,252 atau 25,2 \%, sedangkan ETR terendah sbesar 0,107 atau $10,7 \%$ dan menggambarkan agresivitas pajak tertinggi. Total data yang dimasukkan dalam pengolahan data yaitu 72 dari 12 perusahaan selama 6 tahun pengamatan. Hanya 7,7\% rata-rata kepemilikan manajerial perusahaan manufaktur yang dimasukkan kedalam sampel, dengan nilai tingkat kepemilikan manajerial tertinggi $38 \%$. Yang mendominasi kepemilikan perusahaan sampel adalah kepemilikan institusional, dengan rata-rata lebih dari $60 \%$. Rata-rata likuiditas menyentuh angka 2,4 dan current ratio atau likuiditas terendah adalah 1,1. Presentase wanita dalam posisi dewan perusahaan masih dibawah $1 / 4$ total dewan perusahaan, yaitu $24,2 \%$. 


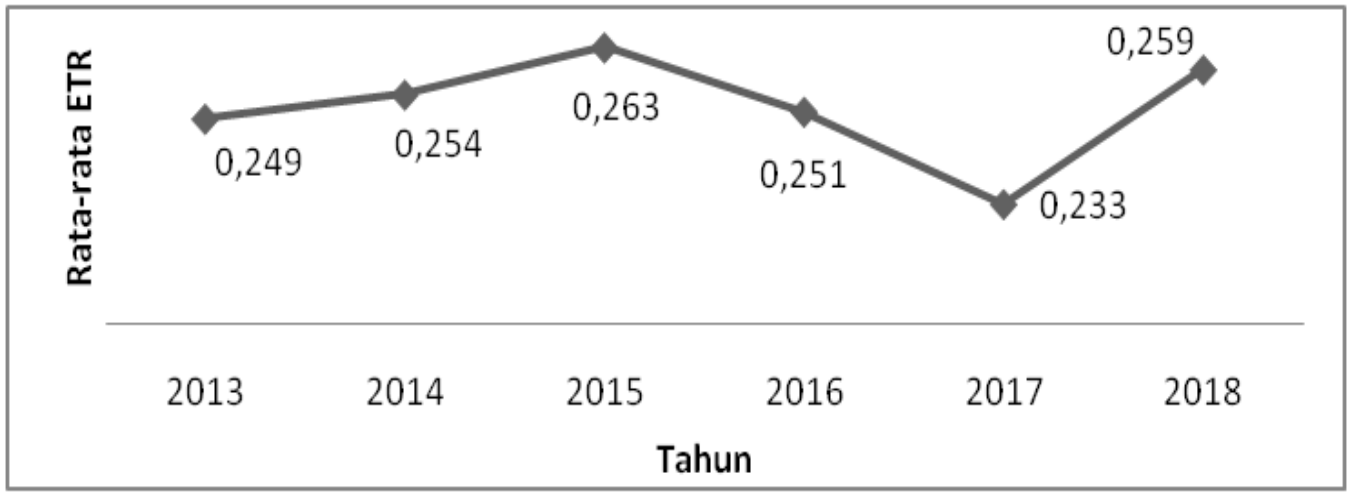

Gambar 2. Grafik Rata-rata ETR

Sumber : Pengolahan data (2019)

Hasil yang ditunjukkan dalam Gambar 2. dapat disimpulkan bahwa rata-rata ETR guna menggambarkan tingkat agresivitas pajak dari tahun 2013-2018 mengalami fluktuasi, dan berada dititik terendah 0,233 atau 23,3\% atau agresivitas paling tinggi dalam tahun penelitian. Sempat terjadi tren membaik dalam presentase ETR dari tahun 2013, 2014, dan 2015 akan tetapi menurun di tahun 2016 dan 2017, hingga terjadi penguatan kembali di tahun 2018.

\section{Model Regresi Data Panel}

Model Random Effect lebih tepat dipakai dalam penelitian ini setelah dilakukan pengujian pemilihan model. Menurut Gujarati \& Porter (2009) karena penelitian ini random effect model yang digunakan, maka tidak perlukan uji asumsi klasik.

Tabel 4. Model Regresi

\begin{tabular}{cr}
\hline Variable & \multicolumn{2}{c}{ Coefficient } \\
\hline C & 0,211047 \\
M_OWN & 0,047186 \\
I_OWN & $-0,016332$ \\
CR & 0,014617 \\
GD & 0,049313 \\
\hline \multicolumn{2}{l}{ Sumber : Pengolahan data (2019) }
\end{tabular}

Menurut tabel 4. didapat model regresi untuk dipakai pada penelitian ini adalah sebagai berikut :

$$
\begin{aligned}
\mathrm{Y}= & 0,211047+0,047186 \text { M_OWN }-0,016332 \text { I_OWN + 0,014617 CR + 0,049313 } \\
& \mathrm{GD}+\mathrm{e}
\end{aligned}
$$

Ket :

Y : $\quad$ Agresivitas pajak (ETR)

0,211047 : Kostanta

M_OWN : Kepemilikan manajerial

I_OWN : Kepemilikan institusional

CR : Likuiditas/Current Ratio

GD : Gender diversity pada dewan

E : $\quad$ Error term

Tabel 5. Hasil Uji Simultan (Uji F)

\begin{tabular}{ccccc}
\hline$F_{\text {hitung }}$ & $F_{\text {tabel }}$ & Prob. & Standar & Kesimpulan \\
\hline 2,976529 & 2,74 & 0,025258 & $<0,05$ & Model Layak \\
\hline
\end{tabular}




\section{Sumber : Pengolahan data (2019)}

Dengan $F_{\text {tabel }}$ sebesar 2,74 maka dari Tabel 5. menunjukkan bahwa nilai $F_{\text {hitung }}>$ $F_{\text {tabel }}$ yaitu 2,976529 $>2,74$ dan nilai prob 0,025258 $<0,05$. Maka variabel yang dipakai, yaitu kepemilikan manajerial, kepemilikan institusional, likuiditas dan gender diversity secara keseluruhan mempengaruhi agresivitas pajak.

\begin{tabular}{lrrrl}
\multicolumn{6}{c}{ Tabel 6. Hasil Uji Hipotesis (Uji t) } \\
\hline Variabel & \multicolumn{1}{c}{ thitung } & \multicolumn{1}{c}{ tabel } & Prob. & Std. \\
\hline M_OWN & 0,264762 & 1,99601 & 0,7920 & $<0,05$ \\
I_OWN & $-0,184798$ & $-1,99601$ & 0,8539 & $<0,05$ \\
CR & 2,392239 & 1,99601 & 0,0196 & $<0,05$ \\
GD & 0,730647 & 1,99601 & 0,4675 & $<0,05$ \\
\hline \multicolumn{5}{l}{ Sumber : Pengolahan data $(2019)$}
\end{tabular}

Tabel 6. menunjukkan hasil uji t dalam penelitian ini. Dari Tabel 6. tersebut dapat dilihat jika variabel kepemilikan manajerial mempunyai nilai thitung kurang dari t tabel yang mana $0,264762<1,99601$ serta nilai probabilitas $0,7920>0,05$. Hal tersebut berarti menolak $\mathrm{H}_{1}$, maka variabel kepemilikan manajerial tidak mampu mempengaruhi agresivitas pajak.

Sesuai Tabel 6. diatas dapat diketahui bahwa nilai -thitung lebih dari -t tabel yang mana $-0,184798>-1,99601$ dan nilai probabilitas 0,8539 > 0,05 dari kepemilikan institusional. Hal ini berarti $\mathrm{H}_{0}$ diterima dan menolak $\mathrm{H}_{2}$. Maka, variabel kepemilikan institusional tidak mampu mempengaruhi agresivitas pajak.

Variabel likuiditas yang dilihat dengan current ratio berdasarkan Tabel 6. diatas dapat dilihat jika besarnya nilai $t_{\text {hitung }}$ lebih dari tabel yang mana 2,392239 $>1,99601$ dan nilai probabilitas 0,0196 < 0,05. Hal tersebut menjelaskan $\mathrm{H}_{0}$ ditolak dan menerima $\mathrm{H}_{3}$. Sehingga, likuiditas dapat mempengaruhi agresivitas pajak.

Pada uji t untuk variabel gender diversity pada dewan berdasarkan Tabel 6. diatas dapat diketahui bahwa besarnya thitung $<$ tabel yang mana 0,730647 $<1,99601$ serta tingkat probabilitas $0,4675>0,05$. Hal ini berarti $\mathrm{H}_{0}$ diterima dan menolak $\mathrm{H}_{4}$. Maka, agresivitas pajak tidak dapat dipengaruhi oleh variabel gender diversity pada dewan.

Tabel 7. Hasil Koefisien Determinasi

\begin{tabular}{cc}
\hline Adjusted $R$-squared & \multicolumn{1}{c}{ Kesimpulan } \\
\hline 0,100196 & $\begin{array}{l}\text { Pengaruh 10,02 \% terhadap agresivitas pajak dari variabel } \\
\text { bebas }\end{array}$ \\
\hline Sumber : Pengolahan data (2019)
\end{tabular}

Tabel uji koefisien determinasi pada Tabel 7. diatas didapati bahwa variabel kepemilikan manajerial, kepemilikan institusional, likuiditas dan gender diversity pada dewan mampu memberikan pengaruh kepada variabel agresivitas pajak sebesar 10,02 $\%$. Maka, 89,98 \% terpengaruh oleh variabel yang tidak dipakai didalam penelitian ini.

\section{Pembahasan}

Setelah dilakukan pengujian hipotesis terhadap hipotesis pertama, diperoleh hasil bahwa $\mathrm{H}_{1}$ ditolak. Sehingga kepemilikan manajerial tidak dapat mempengaruhi besarnya agresivitas pajak pada perusahaan. Temuan tersebut dapat disebabkan karena proporsi kepemilikan manajerial di perusahaan relatif kecil. Dari sampel yang digunakan rata-rata perusahaan hanya memiliki 3,15 \% dari total saham yang beredar. 
Sehingga pihak manajemen tidak memiliki kekuasaan untuk lebih memberikan keuntungan lebih kepada manajemen dengan melakukan agresivitas pajak. Kepemilikian manajerial yang kecil, menandakan adanya kepemilikan lain yang mendominasi pemegang saham perusahaan. Hasil yang ada pada temuan ini sesuai dengan peneltian lain yang diteliti oleh Octaviani \& Sofie (2018). Penelitian ini hasilnya juga seperti penelitian Salaudeen \& Ejeh (2018) di nigeria dengan signifikansi 0,05.

Hipotesis kedua, diperoleh hasil bahwa $\mathrm{H}_{2}$ ditolak. Sehingga kepemilikan institusional tidak mampu berpengaruh pada besarnya agresivitas pajak perusahaan. Tingkat kepemilikan institusi yang dominan tidak berdampak terhadap ETR yang dipakai sebagai pengukur seberapa tinggi tingkat agresivitas pajak. Perusahaan manufaktur yang kebanyakan kepemilikan sahamnya dimiliki oleh institusional tidak mendorong perusahaan untuk memperoleh keuntungan sebesar-besanya dengan mengurangi pajak yang diakui. Hal tersebut dapat disebabkan karena perusahaan mengharapkan reputasi perusahaan terbangun dengan baik dipersepsi investor maupun calon investor. Temuan tersebut sesuai dengan teori keagenan yang beranggapan tingkat kepemilikan oleh institusi dapat meningkatkan pengawasan, dan mempengaruhi perusahaan melalui manajemen untuk lebih disiplin dan mematuhi aturan perpajakan yang ada (Octaviani \& Sofie, 2018). Sesuai dengan penelitian Octaviani \& Sofie (2018) dan Sadjiarto et al., (2019) kepemilikan institusianal tidak berdampak pada agresivitas pajak.

Pengujian hipotesis terhadap hipotesis ketiga, diperoleh hasil bahwa $\mathrm{H}_{3}$ diterima. Sehingga likuiditas atau current ratio mampu mempengaruhi agresivitas pajak. Bagaimana perusahaan bisa memenuhi utang jangka pendek merupakah likuiditas. Apabila sebuah perusahaan mempunyai current ratio yang semakin tinggi maka perusahaan dianggap dalam keadaan sehat. Sebaliknya apabila likuiditas perusahaan semakin kecil, hal tersebut menunjukkan keadaan perusahaan kurang baik. Untuk memperoleh likuiditas yang tinggi, perusahaan akan berusaha menyisihkan pendapatan untuk periode lainnya. Jika laba yang didapat rendah akan mepengaruhi likuiditas perusahaan akan ikut turun pula. Dan menyebabkan besarnya likuiditas dan agresivitas pajak akan berjalan beriringan pergerakannya. Hasil penelitian yang sesuai dengan penelitian oleh Kariimah \& Septiowati (2019), Djohar \& Rifkhan (2019).

Pada pengujian hipotesis terhadap hipotesis keempat, diperoleh hasil bahwa $\mathrm{H}_{4}$ ditolak. Sehingga gender diversity pada dewan tidak dapat mempengaruhi perusahaan agresif dalam pajak. Proporsi dewan perusahaan wanita pada perusahaan manufaktur relatif kecil jika dibandingkan proporsi dewan perusahaan pria. Sehinggga gender diversity pada dewan tidak mampu mempengaruhi agresivitas pajak perusahaan. Temuan ini juga dapat disebabkan karena gender diversity pada dewan tidak memiliki hubungan pada litelatur yang mengemukakan jika wanita mempunyai kehati-hatian dan lebih mementingkan citra perusahaan. Temuan ini sependapat seperti penelitian yang telah diteliti oleh Oyenike, Olayinka, \& Emeni (2016), Edwin \& Victor (2019) dan Bosun-Fakunle, Funmilayo, Josiah, Mary, \& Jacob (2019) yang dilakukan di Nigeria.

\section{Simpulan}

Maksud penellitian dilaksanakan untuk memperoleh dan menganalisa kepemilikan manajerial, kepemilikan institusional, likuiditas (CR), dan gender diversity pada dewan terhadap agresivitas pajak. Sampel yang memenuhi kriteria purposive sampling adalah 12 perusahaan manufaktur pada rentang waktu 2013 hingga 2018. Regresi data panel digunakan untuk mendapatkan hasil penelitian. Pengujian 
hipotesis didapati hanya likuiditas (diproksikan dengan current ratio) yang mampu mempengaruhi tingkat agresivitas pajak perusahaan. Sementara kepemilikan manajerial, kepemilikan institusional, dan gender diversity pada dewan tidak mampu mempengaruhi agresivitas pajak. Temuan tersebut mengindikasikan kepemilikian manajerial dengan presentase relatif kecil tidak mampu mempengaruhi keputusan perpajakan dalam sebuah perusahaan. Kepemilikan institusional dapat meningkatkan pengawasan, dan mempengaruhi perusahaan melalui manajemen untuk lebih disiplin dan mematuhi aturan perpajakan. Likuiditas akan mempengaruhi laba perusahaan yang juga akan mempengaruhi agresivitas pajak. Gender diversity pada dewan tidak memiliki hubungan dengan pendapat yang beranggapan bahwa wanita memiliki kehati-hatian dan lebih mementingkan citra perusahaan. Untuk investor serta calon investor dapat memakai peneltian ini sebagai salah pertimbangan ketika akan menanamkan saham di sebuah perusahaan dengan melihat likuiditas atau current ratio. Maka dapat sebisa mungkin dipertimbangkan tingkat agresivitas pajak perusahaan sejalan dengan current ratio. Manajemen harus dapat mengambil keputusan yang paling tepat mengenai penanganan perpajakan perusahaan. Serta peneliti kedepannya dapat mempergunakan hasil temuan penelitian ini menjadi salah satu referensi pengembangan penelitian yang lebih baik mengenai agresivitas pajak.

\section{Saran}

Penelitian ini terpaku untuk sampel pada perusahaan sektor manufaktur maka temuan penelitian tidak bisa digeneralisasikan di perusahaan pada sektor lain. Variabel independen baru mampu mempengaruhi variabel dependen sebesar 10,02 \%. Dalam menggambarkan agresivitas pajak, peneliti hanya menggunakan ETR yang hanya dilihat dari beban pajak yang dibayarkan. Penelitian kedepan bisa memakai perusahaan sektor lain seperti sektor real estate dan properti atau sektor perbankan, sehingga dapat menambah referensi tentang agresivitas pajak. Menambahkan variabel lain seperti beban iklan dan koneksi politik guna menambah tingkat pengaruh variabel independen terhadap agresivitas pajak. Serta memakai indikator lainya seperti contoh BTD atau Book Tax Difference guna menggambarkan besarnya agresivitas pajak.

\section{Referensi}

Bosun-Fakunle, Funmilayo, Y., Josiah, Mary, \& Jacob, O. B. (2019). Board of Directors Characteristics And Tax Aggressiveness. International Journal of Scientific and Management Research, 5(1), 133-152.

Djohar, C., \& Rifkhan. (2019). Pengaruh Likuiditas dan Ukuran Perusahaan terhadap Agresivitas Pajak (Studi Empiris Pada Perusahaan Manufaktur Yang Terdaftar Di Bursa Efek Indonesia Tahun 2012-2017). Renaissance, 4(01), 523-532.

Edwin, O. A., \& Victor, 0. (2019). Corporate Board Characteristic and Tax Aggressiveness : A Study of Manufacturing Firms in Nigeria. Global Journal For Research Analysis, 8(4), 245-251.

Gujarati, D. N., \& Porter, D. C. (2009). Basic of Econometric, Fifth Edition. In Econometrics. https://doi.org/10.1007/978-1-137-37502-5_17

Kariimah, M. atun, \& Septiowati, R. (2019). Pengaruh Manajemen Laba dan Rasio Likuiditas terhadap Agresivitas Pajak. Jurnal Akuntansi Berkelanjutan Indonesia, 
2(1), 17-38.

Kementrian Keuangan Republik Indonesia. (2019). APBN 2019. Retrieved November 2, 2019, from kemenkeu.go.id/apbn2019

Kompas. (2019, March 24). Ekspansif, Industri Manufaktur Masih Topang Pertumbuhan Ekonomi. Retrieved from money.kompas.com/read//2019/03//14/201720326/ekspansif-industrimanufaktur-masih-topang-pertumbuhan-ekonomi

Lanis, R., Richardson, G., \& Taylor, G. (2017). Board of Director Gender and Corporate Tax Aggressiveness: An Empirical Analysis. Journal of Business Ethics, 144(3), 577-596. https://doi.org/10.1007/s10551-015-2815-2815-x

Makhfudloh, F., Herawati, N., \& Wulandari, A. (2018). Pengaruh Corporate Social Responsibility Terhadap Perencanaan Agresivitas Pajak. Jurnal Akuntansi Dan Bisnis, 18(1), 48-60.

Nurjanah, I., Hanum, A. N., \& Alwiyah. (2018). Pengaruh Likuiditas , Leverage , Corporate Social Responsibility , Ukuran Perusahaan dan Komisaris Independen terhadap Agresivitas Pajak Badan. Seminar Nasional Mahasiswa Unimus, 1, 432-438.

Nurlaela, S., Mursito, B., Kustiyah, E., \& Hartono, S. (2019). Asset Turnover , Capital Structure and Financial Performance Consumption Industry Company in Indonesia Stock Exchange. International Journal of Economics and Financial Issues, 9(3), 297-301. https://doi.org/https://doi.org/10.32479/ijefi.8185

Octaviani, R. R., \& Sofie. (2018). Pengaruh Good Corporate Governance, Capital Intensity.Ratio, Leverage, Dan Financial Distress Terhadap Agresivitas Pajak Pada Perusahaan Tambang Yang Terdaftar Di BEI Tahun 2013-2017. 5(2), 253268. https://doi.org/http://dx.doi.org/10.25105/jat.v5i2.4848

Onyali, C. I., \& Okafor, T. G. (2018). Effect of Corporate Governance Mechanisms on Tax Aggressiveness of Quoted Manufacturing Firms on the Nigerian Stock Exchange. Asian Journal of Economics, Business and Accounting, 8(1), 1-20. https://doi.org/10.9734/AJEBA/2018/38594

Oyenike, O., Olayinka, E., \& Emeni, F. (2016). Female Directors and Tax Aggressiveness of Listed Banks in Nigeria. 3rd International Conference on African Development Issues, 293-299.

Petta, B. C., \& Tarigan, J. (2017). Pengaruh Kepemilikan Institusional Terhadap Kinerja Keuangan Melalui Struktur Modal Sebagai Variabel Intervening pada Perusahaan Manufaktur yang Terdaftar Dalam Bursa Efek Indonesia (BEI). Business Accounting Review, 5(2), 625-634.

Prasista, P. M., \& Setiawan, E. (2016). Pengaruh Profitabilitas dan Pengungkapan Corporate Social Responsibility Terhadap Agresivitas Pajak Penghasilan Wajib 
Pajak Badan. E-Jurnal Akuntansi Universitas Udayana, 17(3), 2120-2144.

Sadjiarto, A., Florencia, \& Nevanda, O. (2019). Effects of Political Connections and Corporate Governance on Tax Aggressiveness in Indonesian Service and Banking Sectors. Journal of Economics and Business, 2(1), 190-204. https://doi.org/10.31014/aior.1992.02.01.79

Salaudeen, Y. M., \& Ejeh, B. U. (2018). Equity Ownership Structure And Corporate Tax Aggressiveness: The Nigerian Context. Research Journal of Business and Management, 5(2), 90-99. https://doi.org/10.17261/Pressacademia.2018.828

Salman, K. R., Anshori, M., \& Tjaraka, H. (2018). New Insights Of Shariah Maqashid Index As Determinant Of Tax Aggressiveness Level. International Journal of Business and Management Invention (IJBMI), 7(6), 37-45.

Simarmata, A. P. P., \& Cahyonowati, N. (2014). Pengaruh Tax Avoidance Jangka Panjang Terhadap Nilai Perusahaan dengan Kepemilikan Institusional sebagai Variabel Pemoderasi. DIPONEGORO JOURNAL OF ACCOUNTING, 3(3), 1-13.

Singal, P. A., \& Putra, I. N. W. A. (2019). Pengaruh Kepemilikan Institusional, Kepemilikan Manajerial, dan Kepemilikan Asing Pada Pengungkapan Corporate Social Responsibility. E-Jurnal Akuntansi, 298(1), 468-484.

Wijaya, D., \& Saebani, A. (2019). Pengaruh Pengungkapan Corporate Social Responsibility, Leverage, Dan Kepemilikan Manajerial Terhadap Agresivitas Pajak. Widyakala, 6(1), 55-776.

Wijayanti, A., Wijayanti, A., \& Chomsatu, Y. (2017). Pengaruh Karakteristik Perusahaan, GCG dan CSR terhadap Penghindaran Pajak. Journal of Economic and Economic Education, 5(2), 113-127. 